\title{
Wybrane trudności w badaniach terenowych i sposoby (zaistniałe i możliwe) zabezpieczania się przed nimi na przykładzie badań z udziałem rodziców dorosłych dzieci uzależnionych od alkoholu oraz przedstawicieli instytucji leczenia i wsparcia społecznego
}

\author{
Selected difficulties in field studies and ways \\ (existing and possibly) to protect against them \\ on the example of research involving parents of adult \\ children addicted to alcohol and representatives of treatment \\ and social support institutions
}

\begin{abstract}
Abstrakt
Celem artykułu jest ukazanie wybranych trudności, które pojawiały się podczas badań z udziałem rodziców dorosłych dzieci uzależnionych od alkoholu oraz przedstawicieli instytucji pomocowych dla rodzin z wyżej wymienionym problemem. W artykule przedstawiono również sposoby (zaistniałe i możliwe) radzenia sobie ze wspomnianymi ograniczeniami. Przedmiotem moich rozważań są trudności, które wynikały ze specyfiki wykorzystanej metodologii badań (metodologia teorii ugruntowanej), a także z charakteru badanego zjawiska społecznego. Był nim proces „stawania się" rodzicem dorosłego dziecka uzależnionego od alkoholu oraz doświadczenia towarzyszące temu procesowi. Poruszane zagadnienia stanowią refleksje własne autorki będące wynikiem przeprowadzonych zespołowo wywiadów narracyjnych z rodzicami dorosłych osób uzależnionych od alkoholu oraz wywiadów swobodnych z przedstawicielami instytucji leczenia i wsparcia społecznego.
\end{abstract}

Słowa kluczowe: trudności, metodologia teorii ugruntowanej, wywiad, rodzice, uzależnienie od alkoholu

\section{Wprowadzenie}

Analizując literaturę przedmiotu, można zauważyć, że w dyskursie naukowym jest niewiele pozycji dotyczących sytuacji rodziców osób dorosłych uzależnionych od alkoholu (Szczepanik i Okólska, 2018). Badania naukowe, które poruszają tematykę związaną z uzależnieniem od alkoholu w kontekście rodziny, dotyczą głównie dzieci (w tym przeważnie dorosłych dzieci) oraz żon bądź partnerek życiowych osób mających problem alkoholowy (por. Scharf i in., 2004; Leadley, Clark i Caetano, 2000; Tsirigotis i Gruszczyński, 2001; Grzegorzewska 
i Cierpiałkowska, 2015). Rodzice pojawiają się jedynie jako członkowie większej grupy określanej jako „bliscy krewni” osób uzależnionych od alkoholu (por. Orford i in., 2017).

Co więcej, analiza literatury przedmiotu badań pozwoliła stwierdzić, że były realizowane również badania, które dotyczą sytuacji rodziców dorosłych osób uzależnionych, ale od narkotyków i innych substancji psychoaktywnych (por. Zucker, 2015; Dion, 2014). Stanowiło to punkt wyjścia do badań realizowanych przez zespół Pracowni Pedagogiki Specjalnej na Wydziale Nauk o Wychowaniu Uniwersytetu Łódzkiego w ramach projektu naukowego pt. „Rodzina w systemie wsparcia społecznego i pomocy osobom z problemem alkoholowym. Badania biograficzne z udziałem rodziców (dorosłych) dzieci uzależnionych od alkoholu". Projekt realizowano jako zadanie tematu „Wspieranie badań naukowych w obszarze problemów wynikających z używania alkoholu”. Celem badań było zrekonstruowanie swoistego procesu „stawania się” rodzicem (dorosłego) dziecka z problemem alkoholowym, tj. nabywania określonej roli społecznej (z całym jej bagażem oczekiwań społecznych oraz kulturowych powinności, nakazów i norm wynikających z rodzinnych więzi). W badaniach wykorzystano metodologię teorii ugruntowanej. Zostały przeprowadzone wywiady biograficzne (por. Kaźmierska, 2004; Szczepanik, 2015) z rodzicami oraz wywiady swobodne z przedstawicielami instytucji (por. Konecki i in., 2012).

Ramy teoretyczne w badaniach z udziałem rodziców dorosłych dzieci uzależnionych od alkoholu wyznaczały założenia interakcjonizmu symbolicznego, a co za tym idzie perspektywę poznawczą stanowił paradygmat interpretatywny (Hałas, 2006). Wybór orientacji jakościowej w badaniach naukowych był podyktowany faktem, że dostarcza ona możliwości analizy fragmentów rzeczywistości społecznej w sposób nieuchwytny dla podejścia ilościowego (Glaser i Strauss, 2009; por. Michel, 2016). Metodologia teorii ugruntowanej to zbiór określonych procedur badawczych, które pozwalają na zrekonstruowanie fragmentu rzeczywistości społecznej przejawiającej się jako proces (Konecki, 2000). Jednocześnie stawiają one przed badaczem swoiste wymagania, ale dzięki tym procedurom można odtworzyć proces nabywania konkretnych ról społecznych, określany w literaturze jako proces „stawania się" (Konecki, 2008; por. Szczepanik, 2015; Ślęzak, 2009). Jednak wykorzystywanie metodologii ugruntowanej $\mathrm{i}$ jej procedur rodzi trudności natury metodologicznej i etycznej (Chomczyński, 2006; Charmaz, 2009). Ponadto ich źródłem, pojawiającym się w procesie badawczym, jest samo zjawisko społeczne poddawane analizie. $W$ tym przypadku są to doświadczenia rodziców dorosłych osób uzależnionych od alkoholu wynikające z zaangażowania w rozwiązywanie problemów życiowych dorosłego syna lub córki (por. Męcfal, 2012). Są one związane nie tylko $z$ analizą zdobytego materiału empirycznego, ale także z jego pozyskiwaniem.

W niniejszym opracowaniu zamierzam podjąć próbę przedstawienia wybranych przeze mnie trudności oraz możliwych lub zaistniałych sposobów ich rozwiązywania, jakie pojawiały się na drodze realizacji badań z udziałem rodziców dorosłych osób uzależnionych od alkoholu oraz przedstawicieli instytucji wsparcia osób i rodzin z problemem uzależnienia od alkoholu. Ze względu na procedurę 
badawczą oraz przedmiot badań trudności, które wskażę, mają charakter metodologiczny i etyczny, a także związane są z samą organizacją procesu badawczego (por. Męcfal, 2016).

\section{Trudności pojawiające się na drodze procesu badawczego}

Pierwszy problem, który pojawił się przy gromadzeniu materiału empirycznego, był związany z pozyskiwaniem kontaktów do rodziców, którzy mogliby ze względu na swoje doświadczenia udzielić wywiadu biograficznego. Biorąc pod uwagę fakt, że $w$ dyskursie naukowym jest tak niewiele badań $z$ udziałem rodziców dorosłych osób uzależnionych od alkoholu (Szczepanik i Okólska, 2018), wydawać by się mogło, że nie będzie problemu z dotarciem do takich osób. Dodatkowo należy pamiętam o tym, że do tej pory w Polsce nikt nie przeprowadzał takich badań. Podstawową metodą pozyskiwania kontaktów do „informatorów” była metoda „kuli śnieżnej” (snowball sampling) (Babbie, 2004). Polega ona na nielosowym doborze rozmówców, w której osoba udzielająca wywiadu podaje kontakt do kolejnej. W przypadku omawianych badań metodę wykorzystywano przy rozmowach z instytucjami pomocowymi, w których organizowano na przykład grupy wsparcia dla rodziców osób uzależnionych od alkoholu. Innym sposobem, wykorzystującym wspomnianą metodę, był kontakt $z$ terapeutami, kuratorami, pracownikami socjalnymi, którzy udzielali wywiadów swobodnych. Działo się to na zasadzie pozostawienia formularza informacyjnego dla rodziców. Jednak ani jedna, ani druga forma nie przyniosła spodziewanych rezultatów, czyli nie dostarczyła przewidywanej grupy kontaktów do rodziców. Nie dlatego, że rodzice dorosłych dzieci uzależnionych od alkoholu nie korzystają z pomocy instytucji formalnych. Za powód odmowy część rodziców podaje, że nie chce udzielać wywiadów, w których mieliby opowiadać o swoich trudnych doświadczeniach ze swoimi dorosłymi synami czy córkami, którzy mają problem alkoholowy. Wskazywali oni na poczucie wstydu lub niechęć przed powracaniem do przykrych wspomnień (por. Pawłowska, 2012).

Kolejnym sposobem docierania do rodziców były rozmowy badaczy w prozaicznych sytuacjach codziennych. Często w sposób przypadkowy nakierowują one na kontakt z osobami, które mogłyby wziąć udział w badaniach (na przykład czekanie w kolejce u lekarza, gdzie ktoś obcy wspomina, że ma kontakt z takim rodzicem albo sam nim jest). O ile sytuacje $z$ udziałem osób nieznajomych badaczowi są neutralne, o tyle docieranie do osób mogących udzielić wywiadu za pośrednictwem osób znajomych rodzi wątpliwości etyczne. Ostatecznie okazuje się, że jest to sposób mało skuteczny w dotarciu do „informatorów” lub tworzy niesprzyjającą barierę między badaczem a osobą udzielającą wywiadu. W ostateczności może to doprowadzić do ukrycia pewnych informacji, które są znaczące przy analizie materiału empirycznego (por. Dzwonkowska-Godula i Stempień, 2014). Innym powodem odmowy rodziców może być poczucie wstydu, w tym przypadku przed osobami znajomymi, a szczególnie w małych miejscowościach i wsiach, nawet jeśli tylko kontakt został przekazany przez osobę 
znajomą. W wywiadach zwracali na to uwagę przedstawiciele instytucji pomocowych, szczególnie małych aglomeracji.

Ponadto w docieraniu do „informatorów” zostały wykorzystane portale społecznościowe. Jednak ten sposób okazał się dostarczać głównie kontakty do innej grupy osób niż ta, która była niezbędna do udzielenia wywiadów. Na opublikowaną prośbę o kontakt z rodzicami dorosłych osób uzależnionych od alkoholu przeważnie odpowiadały dzieci uzależnionych od alkoholu rodziców. Natomiast gdy pojawiała się prośba o kontakt z babciami i dziadkami tych dzieci, często nie był on możliwy z powodu śmierci, dalekiego miejsca zamieszkania czy braku relacji z nimi.

Docieranie do rodziców osób dorosłych z problemem alkoholowym nie stanowi jedynego problemu, jeśli chodzi o samą organizację badań. Wywiad narracyjny posiada określone reguły metodologiczne, które należy wcielić w życie, co generuje kolejne trudności. Zdarzają się sytuacje, w których narratorzy, po wstępnej zgodzie na udzielenie wywiadu, wycofują się, gdy pojawia się moment udzielenia zgody na nagrywanie rozmowy dyktafonem (por. Szczepanik, 2012). Do jednej z podstawowych zasad prowadzenia wywiadu narracyjnego należy zapewnienie przez badacza poczucia bezpieczeństwa i anonimowości rozmówcy (Kaźmierska, 2004). Jednak to czasami nie wystarcza. Rozmówca pomimo zapewnienia przez badacza anonimowości oraz wyjaśnienia, na czym polegają procedury anonimizacji (por. Kaźmierska, 2014; Niedbalski i Ślęzak-Niedbalska, 2016), nie chce udzielić zgody na nagrywanie, a jest ona warunkiem zasadniczym w wywiadzie narracyjnym. Jest to zrozumiałe, ponieważ osoba udzielająca wywiadu dostarcza badaczowi informacji o swoim prywatnym życiu. W przypadku rodziców dorosłych dzieci uzależnionych od alkoholu przekazuje informacje o trudnych wydarzeniach z własnego życia. W takich sytuacjach czasami pomaga stworzenie klimatu „zwykłej rozmowy” podczas wywiadu, ponieważ zmniejsza to dystans osoby biorącej udział w badaniach do całej sytuacji (Kaźmierska, 2004; por. Szczepanik, 2012). Polega to na przeprowadzeniu przez badacza krótkiej rozmowy z narratorem na temat zupełnie niezwiązany z treścią wywiadu. Taka rozmowa często powoduje, że osoba, która wycofała zgodę na nagrywanie, ostatecznie jej udziela.

Inna trudność, która pojawiała się w trakcie przeprowadzania wywiadu, już nie tylko z rodzicem, ale także z przedstawicielami instytucji pomocowych dla osób z problemem alkoholowym, to charakter nawiązującej się interakcji pomiędzy badaczem a osobą udzielającą wywiadu (por. Ślęzak, 2018). Podczas przeprowadzania wywiadów z rodzicami u badaczy pojawiała się trudność w postaci pytania: „Jak bardzo można się zagłębić w świat badanych?”. Innymi słowy, w jaki sposób zadawać pytania, jak rozmawiać, by udzielający wywiadu nie poczuł się w trakcie rozmowy niekomfortowo i tak, by nie poruszyć zbyt kłopotliwych czy drażliwych tematów dotyczących jego życia. Składa się na to już sam wybór miejsca, w którym wywiad będzie udzielany - czy w domu narratora, w instytucji pracy badacza, w parku, czy w innym miejscu mniej lub bardziej neutralnym. W prowadzeniu wywiadów z reguły każde miejsce skutkuje pojawieniem się asymetrii w relacji badacz-narrator i ma swoje przełożenie na to, jakich informacji udzieli rozmówca, ponieważ wynika to z jego poczucia komfortu podczas wywiadu (por. Rancew-Sikora i Cymbrowski, 2016). Było to odczuwalnie również w omawianych badaniach. 
Trudność związana z tym, jak bardzo badacz może zagłębić się w świat badanych, objawia się również w dodatkowych pytaniach badacza. Zgodnie z etapami prowadzenia wywiadów narracyjnych pytania badacza mogą pojawiać się po dłuższej wypowiedzi narratora będącej odpowiedzią na pytanie inicjujące. Głównie w sytuacjach, gdy badacz ma jakieś wątpliwości lub coś było dla niego niejasne (Kaźmierska, 2004). Można je nazwać pytaniami uzupełniającymi. Badaczowi trudno jest przewidzieć reakcję osoby udzielającej wywiadu na zadane pytanie. Badacz nie wie, czy nie będzie ono na przykład zbyt wnikliwe i zbyt mocno wkraczające w sferę prywatną rozmówcy. Osoba przeprowadzająca wywiad musi być przygotowana na różne reakcje ze strony udzielającej wywiadu.

Problem na płaszczyźnie relacji badacz-rozmówca pojawiał się również w rozumieniu przez „informatora”, kim jest osoba przeprowadzająca wywiad. W wywiadach z rodzicami dorosłych dzieci uzależnionych od alkoholu pojawiały się sytuacje, w których badacz był kolejną osobą na drodze rodzica, która mogłaby udzielić wsparcia, rady czy jakiegoś rodzaju terapii. Pojawiały się więc prośby o pomoc, o działanie, które miałoby przerwać trudną sytuację rodzica wynikającą z uzależnienia dorosłego dziecka. Takie prośby przekładały się na pojawiające się pytanie o charakterze etycznym po stronie badacza - „czyją jestem rzeczniczką?”. Czy przeprowadzający wywiad w tej sytuacji reprezentuje instytucję, naukę, projekt? Dlatego w takich momentach badacz musi wykazywać się dużą świadomością celowości realizowanych analiz fragmentu rzeczywistości społecznej, tak by nie pozwolić sobie na przykład na obietnice, które będą bez pokrycia. Oczywiście trzeba pamiętać, by wychodzić naprzeciw zadanemu przez rozmówcę pytaniu. W omawianych badaniach polegało to przynajmniej na udzielaniu informacji, gdzie potrzebujący znajdzie pomoc. To też nie znaczy, że osoby przeprowadzające wywiady z rodzicami nie miały ugruntowanej ich celowości, tylko że w przytoczonych sytuacjach mogą nasuwać się takie pytania, nawet jeśli badacz postępuje zgodnie z procedurą. W końcu należy pamiętać, że osoba przeprowadzająca wywiad nie jest maszyną.

Inaczej natomiast objawiały się trudności w relacji badacz-rozmówca w wywiadach z przedstawicielami instytucji pomocowych. Terapeuci, lekarze, pracownicy socjalni biorący udział w badaniach często używali specjalistycznego słownictwa do opisu prostych sytuacji społecznych, których są uczestnikami. Posługiwali się terminologią książkową przy opisie swojej pracy czy problemów jakich doświadczają ich pacjenci/klienci/podopieczni będący rodzicami dorosłych dzieci uzależnionych od alkoholu. Udzielając wywiadu, specjaliści często argumentowali swoje oddziaływania - znów opierając się o specjalistyczną, książkową, prawną wiedzę. W ten sposób omijali rekonstrukcję sytuacji dotyczących współpracy z rodzicami. Często specjaliści dostarczają informacji, jak jest powszechnie lub jak dyktują przepisy prawne. Wreszcie wypowiedzi przedstawicieli instytucji pomocowych są lakoniczne, zwięzłe, przejawiają nieufność wobec badacza. Tutaj również, podobnie jak przy wywiadach narracyjnych z rodzicami, pojawia się pytanie o to, w jaki sposób osoba udzielająca wywiadu rozumie jego celowość i to czyim rzecznikem jest badacz - rodzica, prawa, instytucji? Znów należy dodać, że to nie znaczy, że osoby przeprowadzające wywiady w omawianych badaniach nie były świadome celowości wywiadów, tylko że w przytoczonych sytuacjach mogą nasuwać się 
takie pytania, przysparzając badaczowi trudności. Nawet jeśli jego działania odpowiadają wymogom procedury badawczej.

W takich sytuacjach badacz może posłużyć się pytaniami pomocniczymi, które mają za zadanie nakierować osobę udzielającą wywiadu na przedmiot zainteresowania badań lub pogłębić kwestie jedynie zasygnalizowane w zbyt pobieżnej odpowiedzi. Z reguły takie działania pomagały podczas przeprowadzania wywiadów z przedstawicielami instytucji pomocowych.

Kolejny problem natury etycznej, który pojawił się w omawianych badaniach, to przeżywanie emocji przez badacza. Osoba udzielająca wywiadu narracyjnego może pozwolić sobie na reakcje emocjonalne, które są naturalnym skutkiem wynikającym z przywoływania własnych doświadczeń, szczególnie gdy są one trudne i przykre. Natomiast badacz musi poradzić sobie z własnymi emocjami, pojawiającymi się w toku usłyszanej historii (Dzwonkowska-Godula i Stempień, 2014). Prowadzący wywiad powinien odpowiednio „zarządzać swoimi emocjami” tak, by móc w toku całego wywiadu świadomie realizować jego cele i etapy. Oznacza to, że czasami, w sytuacjach wzbudzających silne emocje, badacz powinien je kontrolować. $Z$ drugiej strony reakcje emocjonalne badacza nie powinny odbiegać od czystych ludzkich reakcji czy odruchów, ponieważ może to być krzywdzące dla osoby udzielającej wywiadu (Engelking, 2001). Innymi słowy - kontrolowanie emocji przez badacza powinno być jak najbardziej naturalne, ponieważ rozmówca może to odebrać jako brak wrażliwości na tematy, o których on mówi i na jego własne reakcje emocjonalne. Jest to trudna sytuacja w momencie, gdy badacz musi zdecydować czy kontynuować dalej wywiad, czy może pozwolić na odstępstwa wynikające z obciążającej emocjonalnie sytuacji. Decyzja ta wynika i jednocześnie przekłada się na dystans i bliskość pomiędzy osobą udzielającą wywiadu a badaczem, ponieważ decyduje to o tym, czy udzielający wywiad poczuje się na tyle swobodnie w towarzystwie badacza, by faktycznie opowiedzieć o wszystkich swoich doświadczeniach. Na pewno „barierą bezpieczeństwa” dla rozmówcy będzie fakt, że badacz jest dla niego osobą nieznajomą, obcą i dodatkowo zobowiązaną utrzymywać tajemnicę zawodową (por. Kaźmierska, 2014; Szczepanik, 2012). Taki dystans jest również pomocny dla samego badacza. Pozwala on przeprowadzającemu wywiad na zachowanie profesjonalnej postawy w sytuacjach, kiedy usłyszana historia jest trudna w odbiorze, co oznacza pojawienie się silnych emocji u badacza na skutek wysłuchania tego, co ma do powiedzenia rozmówca. Znacznie łatwiej jest je kontrolować, gdy osoba udzielająca wywiadu jest dla badacza neutralna.

Przy realizacji wywiadów z rodzicami dorosłych dzieci uzależnionych od alkoholu zdarzały się sytuacje wzbudzające silne emocje. Głównie pojawiały się ze względu na treść opowiadanych historii, jak również niespodziewanych i emocjonalnych reakcji ze strony rodziców. Podczas wywiadów zdarzały się sytuacje, w których rodzic płakał, nawet kilkukrotnie w trakcie jednego wywiadu. W badaniach brali również udział rodzice tych dzieci, które w wyniku długotrwałych skutków uzależnienia od alkoholu umierały, bądź popełniały samobójstwo. Badacz przed przeprowadzeniem wywiadu tego nie wiedział. Trudności wynikające z zaangażowania emocjonalnego w historię rodzica udzielającego wywiadu wpływały na analizę materiału empirycznego - wyłaniało się pytanie „jak to opisać?”. 
W takich sytuacjach badacz powinien mieć na względzie przede wszystkim dobro osoby udzielającej wywiadu i powinien być świadomy skutków, jakie mogą wywołać jego reakcje na rozmówcę.

Należy także przedstawić trudność wynikającą z wybranej metodologii (metodologia teorii ugruntowanej), która dotyczy decyzji zakończenia gromadzenia materiału empirycznego. W przypadku omawianych badań chodzi o prowadzenie wywiadów z rodzicami oraz przedstawicielami instytucji. Na pewno znaczącą rolę odgrywały plany projektu, w ramach którego realizowano omawiane badania. Należy również pamiętać, że metodologia teorii ugruntowanej składa się z konkretnych procedur, które wyznaczają ściśle określone reguły postępowania badawczego (Glaser i Strauss, 2009; Konecki, 2000). Dyktują one również przesłanki wskazujące na zakończenie gromadzenia materiału empirycznego.

W procedurach metodologii teorii ugruntowanej gromadzenie materiału empirycznego oraz analiza danych są realizowane w schemacie kołowym i powinny być wykonywane jednocześnie. Kiedy kategorie tworzone w badaniu zostają nasycone, co oznacza, że nie pojawiają się żadne dodatkowe, wnoszące nowe informacje dane, można zakończyć ich gromadzenie (Glaser i Strauss, 2009; Konecki, 2000; Charmaz, 2009). Innymi słowy - nasycenie oznacza, że jeżeli każda kolejna próbka wskazuje na pewną powtarzalność danych, badacz uzna, że kolejne pobierane próbki nie prowadzą go w żadnym nowym kierunku, a potwierdzają to, co już zostało wypracowane, to może zakończyć pobieranie próbek. Badacz nie może założyć przed badaniami, ile materiału empirycznego zgromadzi. Jednak to nie jest proste, ponieważ zawsze pozostaje margines niepewności, czy kolejna próbka - kolejny wywiad - nie ujawni nowych informacji. Badacz musi zmierzyć się z lękiem przed zarzutem, że być może pobrane próbki nie są wystarczające do ugruntowania teorii.

Jednak w badaniach jakościowych badacz odgrywa znaczącą rolę w procesie gromadzenia oraz analizy danych empirycznych i to, jakie kategorie wyłonił z pozyskanego materiału, oraz ich dalsze występowanie decyduje o teoretycznym nasyceniu próby. Co więcej, wykorzystując metodologię teorii ugruntowanej, warto pamiętać, że zawsze pozostaje pewien margines swobody na kontynuowanie bądź poszerzanie podjętych badań. Warto też pamiętać, by w opisie procesu badawczego być świadomym ograniczeń, które pojawiały się w przebiegu procesu badawczego, by dostarczały informacji na temat kontekstu, w jakim dane empiryczne były gromadzone. Ponadto czasami te ograniczenia mają charakter pragmatyczny i determinowane są przez granice wynikające między innymi z planów projektu.

\section{Podsumowanie}

Badacz powinien mieć świadomość pojawienia się trudności i ograniczeń już w momencie planowania projektu badawczego. Powinien wziąć pod uwagę konsekwencje wynikające $z$ wyboru danej metody badawczej, a także następstwa wynikające z badania konkretnego zjawiska społecznego. Oczywiście nie 
można przewidzieć trudności przed rozpoczęciem procesu badawczego, ale należy od samego początku liczyć się z tym, że mogą się one pojawić (por. Michel, 2015).

W badaniach terenowych, w których badacz ma bezpośredni kontakt $z$ fragmentem rzeczywistości społecznej, musi również liczyć się z konsekwencjami, które będą bezpośrednio oddziaływać na niego samego. Badacz musi pamiętać, że to on jest narzędziem w procesie badawczym. I tak jak zostało przedstawione w niniejszym opracowaniu, może to być pomocne, ale również rodzi wiele trudności, głównie o charakterze etycznym.

W przypadku metodologii teorii ugruntowanej badacz nie wie, jakie trudności mogą się pojawić, ponieważ sama metoda zakłada, by nie przyjmować żadnych założeń przed wejściem w teren (Glaser i Strauss, 2009). Mimo że stosowanie procedur metodologii teorii ugruntowanej rodzi wiele trudności i ograniczeń, to pozwala jednocześnie na odkrycie zjawisk, których badacz nawet nie szukał na początku swojej pracy. Podobnie było $\mathrm{w}$ badaniach $\mathrm{z}$ udziałem rodziców dorosłych dzieci uzależnionych od alkoholu oraz przedstawicieli instytucji pomocowych dla rodzin z problemem alkoholowym. Dochodziło do zmian w samym sformułowaniu problemu badawczego z powodu wyłonionych kategorii, co oczywiście jest naturalną częścią procesu badawczego wykorzystującego metodologię teorii ugruntowanej (por. Konecki, 2000).

Wreszcie należy odnieść się także do ograniczeń, które mogły spowodować, że przedstawione $\mathrm{w}$ niniejszym opracowaniu trudności etyczne czy wynikające $z$ obranej metody badawczej nie stanowią pełnej palety problemów, jakie pojawiły się w badaniach z udziałem rodziców dorosłych osób uzależnionych od alkoholu oraz przedstawicieli instytucji pomocowych dla rodzin z problemem alkoholowym. Przede wszystkim ukazane przeze mnie trudności stanowią perspektywę jednego badacza, stąd przedstawione ograniczenia czy sposoby radzenia sobie z nimi nie są ich ostatecznym obrazem. Co więcej zwróciłam uwagę na te, które według mnie wymagały przybliżenia i wyjaśnienia, być może inny badacz uznałby potrzebę wskazania na problemy, o których ja nie wspomniałam, chociaż ich doświadczyłam.

\section{Bibliografia}

Babbie E. (2004), Podstawy badań społecznych, Wydawnictwo Naukowe PWN, Warszawa.

Charmaz K. (2009), Teoria ugruntowana: praktyczny przewodnik po analizie jakościowej, Wydawnictwo Naukowe PWN, Warszawa.

Chomczyński P. (2006), Wybrane problemy etyczne w badaniach. Obserwacja uczestnicząca ukryta, „Przegląd Socjologii Jakościowych” 2(1), s. 68-87.

Dion K. (2014), "That's what I Mean by a hundred little, a thousand little deaths...": A case study of the grief experienced by the mother of a substance abusing child, „MEDSURG Nursing” 23(6), s. $397-421$.

Dzwonkowska-Godula K., Stempień J. (2014), Od relacji badacz-respondent do relacji psychoterapeuta-pacjent? Wybrane problemy etyczne wywiadów biograficznych, [w:] W. Warzywoda-Kruszyńska (red.), Społeczeństwo, edukacja, praca, Wydawnictwo Uniwersytetu Łódzkiego, Łódź, s. 139-162. 
Engelking B. (2001), Zagłada i pamięć. Doświadczenie Holocaustu i jego konsekwencje opisane na podstawie relacji autobiograficznych, IFiS PAN, Warszawa.

Glaser B., Strauss A. (2009), Odkrywanie teorii ugruntowanej. Strategie badania jakościowego, Zakład Wydawniczy NOMOS, Kraków.

Grzegorzewska I., Cierpiałkowska L. (2015), Pozytywna i negatywna adaptacja dzieci i młodzieży rodziców uzależnionych od alkoholu, „Alcohol Drug Addict” 28(4), s. 221-233.

Hałas E. (2006), Interakcjonizm symboliczny, Wydawnictwo Naukowe PWN, Warszawa.

Kaźmierska K. (2004), Wywiad narracyjny jako jedna z metod $w$ badaniach biograficznych, „Przegląd Socjologiczny" 53(1), s. 71-96.

Kaźmierska K. (2014), Autobiograficzny wywiad narracyjny - kwestie etyczne i metodologiczne w archiwizacji narracji, „Studia Socjologiczne” 214(3), s. 221-238.

Konecki K. (2000), Studia z metodologii badań jakościowych. Teoria ugruntowana, Wydawnictwo Naukowe PWN, Warszawa.

Konecki K (2008), Od redakcji. „Stawanie się” jako problem socjologiczny, [w:] Ł.T. Marciniak (red.), Stawanie się nauczycielem akademickim. Analiza symboliczno-interakcjonistyczna, „Przegląd Socjologii Jakościowej" IV(2), s. I-VI.

Konecki K. i in. (2012), Słownik socjologii jakościowej, Wydawnictwo Difin SA, Warszawa.

Leadley K., Clark C.L., Caetano R. (2000), Couples' drinking patterns, intimate partner violence, and alcohol-related partnership problems, „Journal of Substance Abuse” 11(3), s. 253-263.

Męcfal S. (2012), Problemy badań terenowych - wybrane kwestie metodologiczne, praktyczne oraz etyczne przy badaniu zjawisk „trudnych”, „Przegląd Socjologiczny” 61, s. 155-178.

Męcfal S. (2016), Badacz zjawisk trudno dostępnych w terenie - kwestie etyczne, praktyczne i metodologiczne, „Przegląd Socjologii Jakościowej” XII(3), s. 88-100.

Michel M. (2015), Społeczne usytuowanie pedagoga resocjalizacyjnego w terenowych badaniach jakościowych. Dylematy metodologiczne i etyczne badacza w „trudnym terenie”, „Resocjalizacja Polska" 10, s. 165-179.

Michel M. (2016), Gry uliczne w wykluczenie społeczne w przestrzeni miejskiej. Perspektywa resocjalizacyjna, Wydawnictwo Uniwersytetu Jagiellońskiego, Kraków.

Niedbalski J., Ślęzak-Niedbalska I. (2016), Etyczne, metodologiczne i techniczne aspekty upowszechniania i archiwizacji danych jakościowych, „Rocznik Nauk Społecznych” 44(2), s. 223-241.

Orford J. i in. (2017), The burden experienced by Brazilian family members affected by their relatives' alcohol or drug misuse, „Drugs: Education, Prevention and Policy” 9(3), s. 103-112.

Pawłowska B. (2012), Duma i wstyd jako emocje kierujące zachowaniem. Problemy metodologiczne, „Societas/Communitas” 14(2), s. 39-54.

Rancew-Sikora D., Cymbrowski B. (2016), Dylematy etyczne i ryzyko w badaniach terenowych, „Przegląd Socjologii Jakościowej" 12(3), s. 6-21.

Scharf J.L. i in. (2004), The interaction of parental alcoholism, adaptation role, and familial dysfunction, „Addictive Behaviors” 29(3), s. 575-581.

Szczepanik R. (2012), Zastosowanie techniki wywiadu narracyjnego w badaniach więźniów, „Resocjalizacja Polska" 3, s. 89-105.

Szczepanik R. (2015), Stawanie się recydywistą. Kariery instytucjonalne osób powracających do przestępczości, Wydawnictwo Uniwersytetu Łódzkiego, Łódź.

Szczepanik R., Okólska K. (2018), Zapomniani rodzice (dorosłych) dzieci uzależnionych od alkoholu, „Alkoholizm i Narkomania” 31(4), s. 273-300.

Ślęzak I. (2009), Stawanie się poetą. Analiza interakcjonistyczno-symboliczna, „Przegląd Socjologii Jakościowej" 1, s. 1-175.

Ślęzak I. (2018), Praca nad zaufaniem. Etyczne, praktyczne i metodologiczne wyzwania w relacjach badacz-badani na przykładzie etnografii agencji towarzyskich, „Przegląd Socjologii Jakościowej" XIV(1), s. 138-162.

Tsirigotis K., Gruszczyński W. (2001), Cechy osobowości dorosłych córek i synów alkoholików (DDA) leczonych w PZP, „Alkoholizm i Narkomania” 14(3), s. 365-773.

Zucker D.M. (2015), Concept clarification of grief in mothers of children with an addiction, „JAN Leading Global Nursing Research" 71(4), s. 751-767. 


\section{Abstract}

The aim of the article is to show selected difficulties, which appeared on the way of carrying out research involving parents of adult children addicted to alcohol and representatives of aid institutions for families with an alcohol-related problem. The article also presents ways to deal with them. The object of the study is constituted by difficulties which are related with the research methodology used (methodology of the grounded theory). Also as well as with the nature of the social phenomenon. It was the process of "becoming" the parent of an adult child addicted to alcohol and experience accompanying this process. Issues raised are the author's own reflections.

Keywords: difficulties, methodology of the grounded theory, interview, parents, addiction to alcohol 